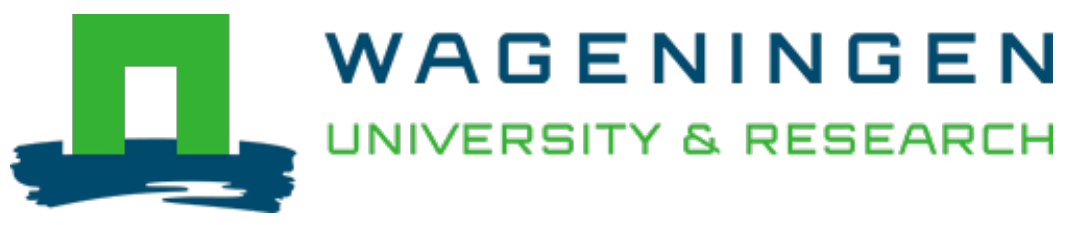

\title{
Avenin diversity analysis of the genus Avena (oat). Relevance for people with celiac disease
}

\author{
Journal of Cereal Science \\ Londono, D.M.; Westende, W.P.C.; Goryunova, S.V.; Salentijn, E.M.J.; Broeck, H.C. et al \\ https://doi.org/10.1016/j.jcs.2013.03.017
}

This article is made publicly available in the institutional repository of Wageningen University and Research, under the terms of article $25 \mathrm{fa}$ of the Dutch Copyright Act, also known as the Amendment Taverne. This has been done with explicit consent by the author.

Article 25 fa states that the author of a short scientific work funded either wholly or partially by Dutch public funds is entitled to make that work publicly available for no consideration following a reasonable period of time after the work was first published, provided that clear reference is made to the source of the first publication of the work.

This publication is distributed under The Association of Universities in the Netherlands (VSNU) 'Article $25 \mathrm{fa}$ implementation' project. In this project research outputs of researchers employed by Dutch Universities that comply with the legal requirements of Article $25 \mathrm{fa}$ of the Dutch Copyright Act are distributed online and free of cost or other barriers in institutional repositories. Research outputs are distributed six months after their first online publication in the original published version and with proper attribution to the source of the original publication.

You are permitted to download and use the publication for personal purposes. All rights remain with the author(s) and / or copyright owner(s) of this work. Any use of the publication or parts of it other than authorised under article $25 \mathrm{fa}$ of the Dutch Copyright act is prohibited. Wageningen University \& Research and the author(s) of this publication shall not be held responsible or liable for any damages resulting from your (re)use of this publication.

For questions regarding the public availability of this article please contact openscience.library@,wur.nl 


\title{
Avenin diversity analysis of the genus Avena (oat). Relevance for people with celiac disease
}

\author{
D.M. Londono ${ }^{\mathrm{a}, *}$, W.P.C. van't Westende ${ }^{\mathrm{a}, \mathrm{b}}$, S. Goryunova ${ }^{\mathrm{c}}$, E.M.J. Salentijn ${ }^{\mathrm{a}, \mathrm{b}}$, \\ H.C. van den Broeck ${ }^{b}$, I.M. van der Meer ${ }^{b, d}$, R.G.F. Visser ${ }^{a}$, L.J.W.J. Gilissen ${ }^{\text {b,d, }}$ \\ M.J.M. Smulders ${ }^{\mathrm{a}, \mathrm{b}, \mathrm{d}, *}$
}

${ }^{a}$ Wageningen UR Plant Breeding, P. O. Box 386, NL-6700 AJ Wageningen, The Netherlands

${ }^{\mathrm{b}}$ Plant Research International, P.O. Box 16, NL-6700 AA Wageningen UR, Wageningen, The Netherlands

${ }^{c}$ Vavilov Institute of General Genetics, Gubkin str. 3, 119991, Moscow GSP-1, Russia

${ }^{\mathrm{d}}$ Allergy Consortium Wageningen, P.O. Box 16, NL-6700 AA Wageningen, The Netherlands

\section{A R T I C L E I N F O}

\section{Article history:}

Received 17 January 2013

Received in revised form

25 March 2013

Accepted 28 March 2013

\section{Keywords:}

Gluten-free

Celiac disease

R5 antibody

G12 antibody

\begin{abstract}
A B S T R A C T
Oat is widely consumed by people with celiac disease (CD). Its safety has been disputed because two peptides from oat avenins can be recognized as T cell epitopes by some CD patients. Differential signals of gluten-specific monoclonal antibodies and in-vitro $T$ cells to oat varieties have suggested the existence of differences in immunogenicity. We aimed to clarify the nature of such responses by cloning avenin genes from 13 Avena species. A single oat plant contained up to 10 avenin genes. Avenin proteins clustered in four groups of which two contained the two avenin CD epitopes. All Avena species examined harbored avenins of these two groups, and as a consequence all contained avenins with the two avenin-specific epitopes, which makes it very unlikely to find oat cultivars that are devoid of these sequences. The established gluten epitopes from wheat, rye and barley were not present in oat avenins; some variants with two and three amino acid substitutions occurred, but they were predicted not to resist proteolysis in the gastro-intestinal tract. Perfect recognition sites of antibodies R5 and G12 were also not present in avenins. Thus, their signals to oat should not be interpreted as differences in immunogenicity for $C D$ patients.
\end{abstract}

(c) 2013 Elsevier Ltd. All rights reserved.

\section{Introduction}

Celiac disease $(C D)$ is an intolerance to gluten proteins (prolamins) from wheat, rye and barley that leads to a chronic inflammation of the small intestine and affects about $1 \%$ of Western population. The only remedy for $\mathrm{CD}$ patients is a gluten-free diet. There is an increasing demand for gluten-free products to diversify this diet and oat is considered an interesting alternative because it contains healthy compounds (essential amino acids, unsaturated fatty acids beta-glucans, polyphenols) that can supplement the diet of patients and help to prevent diabetes and vascular diseases (Andon and Anderson, 2008).

\footnotetext{
* Corresponding authors. Wageningen UR Plant Breeding, P.O. Box 16, NL-6700 AA Wageningen, The Netherlands. Tel.: +31 317480840.

E-mail addresses: Diana.londono@wur.nl (D.M. Londono), wendy.vantwestende@wur.nl (W.P.C. van’t Westende), orang2@yandex.ru (S. Goryunova), elma.salentijn@wur.nl (E.M.J. Salentijn), hetty.busink@wur.nl (H.C. van den Broeck), Ingrid.vandermeer@wur.nl (I.M. van der Meer), richard.visser@wur.nl (R.G.F. Visser), luud.gilissen@wur.nl (L.J.W.J. Gilissen), rene.smulders@wur.nl (M.J.M. Smulders).
}

It has generally been accepted that $\mathrm{CD}$ patients can consume oats without detrimental inflammation of the small intestine (Thompson, 2003). A systematic study with 52 patients revealed that most of them, whether in remission or newly diagnosed, can add moderate amounts (about $50 \mathrm{~g} /$ day) of oats to their gluten-free diet without any harmful effects (Janatuinen et al., 1995). Another study described how children with CD tolerated oats in their gluten-free diet for a period of two years in which they were regularly monitored (Koskinen et al., 2009). Pulido et al. (2009) analyzed the studies published between 1995 and 2009, and concluded that the majority of adults and children with CD can tolerate moderate amounts (from $20 \mathrm{~g} /$ day for children to $70 \mathrm{~g} /$ day for adults) of pure oats. Probably the largest problem with oats for $\mathrm{CD}$ patients is the fact that most commercial oat products are contaminated with wheat (Gelinas et al., 2008). Contamination can start in the field when wheat or barley plants grow among oat plants and are not removed systematically, but contamination can also occur later on in the food production chain, during storage or processing. Consequently, a guaranteed gluten-free oat production chain is an essential requirement for CD-safe oat production. Such a 
chain exist in several Nordic countries (Sweden, Finland) where $70 \%$ of patients eat oats regularly as a healthy component of their gluten-free diet (Salovaara et al., 2010) and it was recently established in The Netherlands. Oat products containing less than $20 \mathrm{ppm}$ gluten are allowed to be labeled and sold as "gluten-free" in Europe, because of its general safety and its contribution to a healthy diet.

Medical research has produced an extensive list of epitopes intrinsically present in wheat, rye and barley that are recognized by T cells from CD patients (Sollid et al., 2012). In wheat, HLA-DQ2/8 T cell epitopes occur in various gluten protein families: $\alpha$ - and $\gamma$ gliadins, LMW- and HMW-glutenins. Presence and number of T cell epitopes per gluten molecule differ among members of these multigene storage protein families (van Herpen et al., 2006) and among individual cultivars (Spaenij-Dekking et al., 2005), due to naturally occurring amino acid substitutions in the epitopes (Mitea et al., 2010). Oat contains only one family of prolamins called avenins, which makes up $10-15 \%$ of the total seed protein content, in contrast to wheat, in which prolamins represent $80 \%$ of the total seed protein content. Four cases of oat avenin-sensitive $C D$ patients have been described and the response has been attributed to three specific avenin-derived peptides that are different from all known $\mathrm{T}$ cell epitopes from wheat, rye and barley (Arentz-Hansen et al., 2004; Lundin et al., 2003; Vader et al., 2003). Recently a new nomenclature for $\mathrm{CD}$ epitopes was released based on unified criteria that the peptides should accomplish in order to be considered CD epitopes (Sollid et al., 2012). This list only includes two avenin-specific epitopes present in oats that can induce T cells.

Recently, a new discussion emerged based on responses of monoclonal antibodies (mAbs) and T cell clones to oat extracts in vitro. Silano et al. (2007) found that avenins from four oat varieties activated peripheral $\mathrm{T}$ cell clones from ten CD children on a glutencontaining diet. Comino et al. (2011) found that protein extracts from two of three groups of commercial oat varieties induced G12 mAb binding, and especially variety OM719 was able to induce proliferation and IFN-gamma production of peripheral blood mononuclear T cells from patients who were on a gluten-containing diet. The reactions were not due to contamination of the oats used. Mujico et al. (2011) observed differences in the binding of mAbs raised against a wheat $\mathrm{LMW}$-glutenin derived peptide to oat cultivars. A possible relation was recently suggested between oat consumption and the persistence of duodenal intraepithelial lymphocytosis in CD patients on a gluten-free diet (Tuire et al., 2012).

These results raised the question whether toxicity in oats may have been overlooked, which would have implications on whether promotion of oat consumption by $\mathrm{CD}$ patients is justified.
Alternative explanations of these results include cross-reactivity of $\mathrm{mAbs}$ with other peptides that are not necessarily immunogenic for $\mathrm{CD}$ patients and promiscuity of T cells that have been induced by wheat gluten and that cross-react with variants of the canonical $\mathrm{T}$ cell epitopes (Anderson et al., 2000; Vader et al., 2003). Unfortunately, only few avenin sequences are known (Chesnut et al., 1989), and diversity within a single oat variety has not been studied, so it is unknown whether peptides in avenins could cause such responses.

The objective of this study was to determine the frequency of avenin-specific T cell epitopes, and whether T cell epitopes known from wheat, rye or barley are present in avenins. We also aimed to determine variation in copy number and sequence similarity among genes, and to estimate diversity between varieties and species. To achieve these objectives, we cloned and sequenced avenin genes present in the commercial hexaploid oat cultivar 'Gigant' and in accessions of 12 diploid and tetraploid Avena species, representing various $\mathrm{A}$ and $\mathrm{C}$ genomes within the genus Avena (Loskutov, 2008). We also analyzed an EST library from another hexaploid oat cultivar, 'Dancer'.

\section{Materials and methods}

\subsection{Plant material}

Genomic DNA of twelve diploid and tetraploid Avena species representing the major genomes in Avena was obtained from the Vavilov Institute of General Genetics, Moscow, Russia (Table 1). We also included the hexaploid Avena sativa cultivar 'Gigant' from which genomic DNA (gDNA) was extracted using the DNeasy Plant Mini kit (Qiagen, Venlo, The Netherlands).

Grains in two different developmental stages (watery and early milk stage) were collected from the hexaploid $A$. sativa $(2 n=6 \times=42) \mathrm{cv}$. 'Gigant' in an agricultural production field located in Munnekezijk, Groningen, The Netherlands. The hulls were removed to classify the grains according to developmental stage. The naked grains were frozen in liquid nitrogen and stored at $-80 \mathrm{C}$ until processing. Messenger RNA was extracted using TRIzol and the RNeasy Plant Mini kit (Qiagen, Venlo, The Netherlands), and cDNA was synthesized using the iScript cDNA Synthesis Kit (Bio-Rad, Veenendaal, The Netherlands).

\subsection{Primer design}

The genes for storage proteins in cereals are often present in multiple copies per genome, which may be highly similar to each

Table 1

Summary of avenin genes obtained from genomic DNA of diploid, tetraploid, and hexaploid Avena species.

\begin{tabular}{|c|c|c|c|c|c|c|c|}
\hline Avena species & Ploidy & Sample ${ }^{a}$ & Cat\# & Genome $^{\mathrm{b}}$ & \# of avenin genes & \# of pseudogenes & $\begin{array}{l}\text { \# of genes with } \\
\text { avenin epitopes }\end{array}$ \\
\hline A. canariensis & $2 \times$ & 121 & k292 & Ac & 6 & 0 & 3 \\
\hline A. clauda & $2 \times$ & 72 & CN 19217 & $\mathrm{Cp}$ & 6 & 1 & 3 \\
\hline A. ventricosa & $2 \times$ & 53 & CN21992 & $\mathrm{Cv}$ & 5 & 1 & 3 \\
\hline A. longiglumis & $2 \times$ & 534 & k87 & $\mathrm{Al}$ & 5 & 0 & 4 \\
\hline A. strigosa & $2 \times$ & 127 & k5196 & As & 7 & 0 & 6 \\
\hline A. pilosa & $2 \times$ & $148 \mathrm{i}$ & CN73755 & $\mathrm{Cp}$ & 5 & 0 & 2 \\
\hline A. prostrata & $2 \times$ & 86 & 2055 & Ap & 5 & 0 & 2 \\
\hline A. damascena & $2 \times$ & 57 & CN 19457 & Ad & 6 & 0 & 2 \\
\hline A. macrostachya & $4 \times$ & 142 & - & $\mathrm{CmCm}$ & 4 & 1 & 3 \\
\hline A. murphy & $4 \times$ & 542 & 2088 & $\mathrm{AC}^{2}$ & 8 & 1 & 4 \\
\hline A. magna & $4 \times$ & 123 & k1852 & $\mathrm{AC}^{2}$ & 6 & 0 & 2 \\
\hline A. insularis & $4 \times$ & 138 & - & $\mathrm{AC}^{2}$ & 5 & 1 & 3 \\
\hline A. sativa cv Gigant & $6 \times$ & - & - & ACD & 10 & 0 & 4 \\
\hline
\end{tabular}

${ }^{a}$ ID of the gDNA of diploid and tetraploid Avena species in the Vavilov Institute of General Genetics, Moscow, Russia.

b Genome $\mathrm{AC}(\mathrm{CD})$ of tetraploid species is represented by $\mathrm{AC}$ in this article. 
other. To obtain avenins from oat, we implemented a strategy used to reliably obtain gamma-gliadin sequences from wheat despite the high similarity between various gene family members, only accepting a sequence if it was obtained in two independent PCR reactions (Salentijn et al., 2012). Primers were designed on conserved regions at the $5^{\prime}$ and $3^{\prime}$ ends of the coding sequence of 5 avenin genes described by Chesnut et al. (1989) and on avenin ESTs from 'Dancer' available in EMBL/GenBank, which assembled into 11 contigs of $>99 \%$ identity (Table 2 ). Forward primers were designed on a part of the avenin signal peptide MKTFLI. Reverse primers were designed on the $3^{\prime}$ end of the avenin genes, the stop codon TAA being present in the center or at the $3^{\prime}$ end of the reverse primer. The primers were synthesised by Biolegio, Nijmegen, The Netherlands. In total, 7 different combinations of the following forward $(F)$ and reverse $(R)$ primers were used:

\section{F2 5'-ATGAAGAACTTCCTCATC- $3^{\prime}$ \\ F4 5'-ATGAGGACCTTCCTCATC-3' \\ Fd1 5'-ATGAARACMTTTCYCATC-3' \\ Fd2 5'-ATGAAGAMCTTYCTCATC-3' \\ R1 5'-AGTGTTCTTAGAAGCCAC-3' \\ R2 5'-AGTCTTCTCAGAAGCCAC-3' \\ R3 5'-AATCTTCTTAGCAACCAC-3' \\ R6 5'-CCCTTATAGTCTTCTCAG-3' \\ Rd2 5'-CYCTTRTAGTSTTCTYAG-3'}

\subsection{Cloning and sequencing of avenin genes from gDNA and $c D N A$}

The set of seven primer pairs was used to amplify avenins from cDNA of cv. Gigant and gDNA of diploid and tetraploid Avena species (Table 1). Each reaction contained 50 ng gDNA or $2 \mu \mathrm{l}$ cDNA, $75 \mathrm{mM}$ Tris- $\mathrm{HCl}$ pH 9.0, $20 \mathrm{mM}\left(\mathrm{NH}_{4}\right)_{2} \mathrm{SO}_{4}, 0.01 \%$ (w/v) Tween-20, $2.5 \mathrm{mM}$ $\mathrm{MgCl}_{2}, 250 \mu \mathrm{M}$ of each dNTP, $200 \mathrm{nM}$ of specific primer or $1200 \mathrm{nM}$ of degenerate primer, and $1 \mathrm{U}$ Goldstar Taq (Eurogentec, Liege, Belgium). The PCR reactions were performed in a Dyad Thermal Cycler PTC220 (Bio-Rad) starting with an initial denaturation step for $5 \mathrm{~min}$ at $94^{\circ} \mathrm{C}$ followed by $1 \mathrm{cycle}$ at $94{ }^{\circ} \mathrm{C}$ for $1 \mathrm{~min}, 56{ }^{\circ} \mathrm{C}$ for $1 \mathrm{~min}$ and $72{ }^{\circ} \mathrm{C}$ for $2 \mathrm{~min}$. The $56{ }^{\circ} \mathrm{C}$ annealing temperature was subsequently reduced by $1{ }^{\circ} \mathrm{C}$ for the next 9 cycles, and continued at $47{ }^{\circ} \mathrm{C}$ for the remaining 26 cycles. A final extension followed at $72{ }^{\circ} \mathrm{C}$ for $10 \mathrm{~min}$.

The PCR products, containing a mixture of gene sequences, were ligated into the pGEM $^{\circledR}$-T Easy Vector (Promega Benelux, Leiden, The Netherlands) and used for transformation of E. coli XL1-blue supercompetenT cells (Stratagene Europe, Amsterdam, The Netherlands). The white colonies were picked and grown overnight at $37^{\circ} \mathrm{C}$ in LB-freezing medium into 96-well flat bottom plates. Each colony PCR contained $1 \mu \mathrm{l}$ of overnight culture, $75 \mathrm{mM}$ Tris- $\mathrm{HCl} \mathrm{pH}$ 9.0, $20 \mathrm{mM}\left(\mathrm{NH}_{4}\right)_{2} \mathrm{SO}_{4}, 0.01 \%(\mathrm{w} / \mathrm{v})$ Tween-20, $1.5 \mathrm{mM} \mathrm{MgCl}_{2}, 100 \mu \mathrm{M}$ of each dNTP, $250 \mathrm{nM}$ of both M13 forward and reverse primer and 0.5 U Goldstar Taq (Eurogentec). PCR was performed in a PTC200 (MJ Research, Bio-Rad) with an initial denaturation step at $94{ }^{\circ} \mathrm{C}$ for
5 min followed by 35 cycles of $94^{\circ} \mathrm{C}$ for $30 \mathrm{~s}, 55^{\circ} \mathrm{C}$ for $30 \mathrm{~s}$ and $72{ }^{\circ} \mathrm{C}$ for $2 \mathrm{~min}$ and a final extension step of $72{ }^{\circ} \mathrm{C}$ for $10 \mathrm{~min}$. The colony PCR products were sequenced with M13 forward and reverse primers using the DYEnamic ET Terminator Cycle Sequencing Kit (Amersham Biosciences Benelux, Roosendaal, The Netherlands) on an ABI3710 automated sequencer (Applied Biosystems). On average, 16 clones per product were sequenced.

\subsection{Analysis of sequences}

The traces were checked manually and subsequently assembled using Lasergene 8.0 (DNAStar, Madison, WI). The mismatches within each contig were checked manually on the forward and reverse traces. Only sequences containing SNPs that were supported by two or more clones from at least two different PCR events were considered as genuine. Sequences obtained from cDNA and gDNA of cv. Gigant were assembled into 7 and 10 contigs of $>99 \%$ identical sequences, respectively. Sequences obtained from diploid and tetraploid Avena species assembled into 41 contigs of $>99 \%$ identical sequences; some contigs contained identical avenin genes from different Avena species. The sequences reported in this paper have been deposited in EMBL under Accession numbers FN706441FN706450, HE576937-HE576976, and HE801178-HE801213.

An EST library containing 231 sequences of cv. 'Dancer' found in NCBI on May 2009 was analyzed also. The sequences with accession numbers [NCBI: G0584576.1, G0583621.1 and G0584748.1] were removed from the data set because they did not have the expected size and did not share the common features with the other sequences, e.g. the characteristic presence of eight cysteine residues in the translated amino acid sequence. All sequences were translated into amino acid sequences and used to perform a Bootstrap Neighbor-Joining test (1000 replicates) using MEGA 4.

\subsection{Screening for $C D$ toxic epitopes}

All translated avenin protein sequences were screened for the presence of celiac-immunogenic or -toxic peptides (epitopes) described up to date in the literature (Sollid et al., 2012) as well as all possible variants of these epitopes in oats with 1, 2 or 3 amino acid substitutions. In silico digestion of avenin proteins was done using PeptideCutter (http://expasy.org/) taking into account the specificities of trypsin, pepsin ( $\mathrm{pH} 1.3$, and $\mathrm{pH}>2$ ), and chymotrypsin (high and low specificity).

\subsection{SDS-PAGE}

Oat avenins were extracted from $100 \mathrm{mg}$ of commercial oat flour by addition of $0.5 \mathrm{ml}$ of $50 \%(\mathrm{v} / \mathrm{v})$ aqueous iso-propanol with continuous mixing (MS1 Minishaker, IKA Works, Inc.) at $1000 \mathrm{rpm}$ for $30 \mathrm{~min}$ at room temperature, followed by centrifugation at $10,000 \mathrm{rpm}$ for $10 \mathrm{~min}$ at room temperature. The residue was re-

Table 2

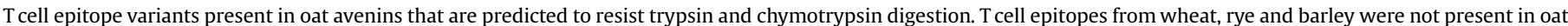

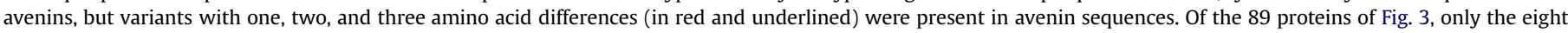
variants listed here resisted in silico trypsin and chymotrypsin proteolysis. None of them remained completely intact if pepsin was also added.

\begin{tabular}{|c|c|c|c|c|c|c|c|c|c|}
\hline \multirow{2}{*}{$\frac{\text { T cell epitopes Deamidated }}{\text { DQ2.5-glia- } \gamma 2 \text { IQPEQPAQL (from wheat) }}$} & \multicolumn{9}{|c|}{ Epitope variants present in oat avenins that are predicted to be resistant to trypsin and chymotrypsin digestion } \\
\hline & $\underline{N}$ & Q & $\mathrm{P}$ & Q & Q & $\underline{Q}$ & A & Q & $\underline{F}$ \\
\hline & $\bar{I}$ & Q & $\mathrm{P}$ & Q & Q & $\underline{\mathrm{L}}$ & $\underline{P}$ & Q & $\underline{\bar{Y}}$ \\
\hline DQ2.5-glut-L2 FSQQQESPF (from wheat) & $\underline{\mathrm{V}}$ & $\underline{Q}$ & Q & $\mathrm{Q}$ & $\mathrm{Q}$ & $\overline{\mathrm{Q}}$ & $\overline{\mathrm{Q}}$ & $\mathrm{P}$ & $\overline{\mathrm{F}}$ \\
\hline DQ2.5-hor-1 PFPQPEQPF (from barley) & $\overline{\mathrm{P}}$ & $\underline{\bar{Y}}$ & $\mathrm{P}$ & $\underline{E}$ & $\underline{Q}$ & Q & Q & $\mathrm{P}$ & $\mathrm{F}$ \\
\hline DQ2.5-sec-1 PFPQPEQPF (from rye) & $\mathrm{P}$ & $\underline{\bar{Y}}$ & $\mathrm{P}$ & $\underline{\bar{E}}$ & $\underline{\mathrm{Q}}$ & Q & Q & $\mathrm{P}$ & $\mathrm{F}$ \\
\hline DQ2.5-ave-1a PYPEQEEPF (from oat) & $\mathrm{P}$ & $\overline{\mathrm{Y}}$ & $\mathrm{P}$ & $\overline{\mathrm{E}}$ & $\overline{\mathrm{Q}}$ & $\mathrm{Q}$ & $\underline{Q}$ & $\mathrm{P}$ & $\underline{I}$ \\
\hline \multirow[t]{2}{*}{ DQ2.5-ave-1b PYPEQEQPF (from oat) } & $\mathrm{P}$ & $\mathrm{Y}$ & $\mathrm{P}$ & $\mathrm{E}$ & Q & Q & $\overline{\mathrm{Q}}$ & $\underline{S}$ & $\underline{I}$ \\
\hline & $\mathrm{P}$ & $\mathrm{Y}$ & $\mathrm{P}$ & $\mathrm{E}$ & Q & Q & Q & $\underline{\mathrm{Q}}$ & $\underline{\mathrm{L}}$ \\
\hline
\end{tabular}


extracted once with $0.5 \mathrm{ml} 50 \%$ (v/v) aqueous iso-propanol. The two obtained supernatants were combined and can be considered to be the complete avenin protein extract, as shown by van den Broeck et al. (2011). The avenin protein content was quantified using the Bio-rad Protein Assay (Bio-Rad), based on the Bradford dye-binding procedure, according to manufacturer's instruction with BSA as a standard. Avenins were separated on SDS-PAGE gels (11\%) using a Hoefer SE 260 mighty small II system (GE Healthcare) followed by staining with PageBlue (Fermentas, Thermo Scientific, St. Leon-Rot, Germany).

\section{Results}

\subsection{The avenins of oat}

The general structure of avenin proteins is depicted schematically in Fig. 1. Similar to other prolamins, they have a high proline and glutamine content, low content of lysine, and they are insoluble in water. In total, 717 avenin sequences were obtained from gDNA of 13 diploid, tetraploid, and hexaploid Avena species containing the three major genomes $(A, D, C)$ that occur within the genus. These sequences assembled in 83 contigs of $>99 \%$ identical sequences, conservatively representing 78 different genes and 5 pseudogenes (with internal stop codons). Some contigs were composed of sequences from different species. The number of genes obtained from diploid and tetraploid accessions ranged from five to seven in diploid species, and from four to eight in tetraploid species. The number of genes obtained from gDNA of the hexaploid A. sativa cultivar 'Gigant' was 10 (Table 1 ).

Gene expression was studied in kernels of 'Gigant' in early stage of development. From cDNA we cloned and sequenced 120 PCR products (from two independent reactions) that assembled into only 7 contigs of $>99 \%$ identical sequences (606-810 bp in length), indicating that 7 of the 10 different avenin genes obtained from gDNA were expressed during early development. It is likely that during later developmental stages of 'Gigant' a few more genes will be expressed since SDS-PAGE analysis of proteins from mature seeds of 'Gigant' showed 12 clear protein bands (Fig. 2). The EST library of cultivar 'Dancer' assembled into 11 contigs (S1).

Diploid species (Avena ventricosa and Avena clauda) and tetraploid species (Avena macrostachya, Avena murphy and Avena insularis) contained one sequence with internal stop codons (Table 1). According to an unrooted neighbor joining analysis, avenin genes clustered into four groups (I-IV; Fig. 3), with Avena species representative of all genomes in each group. From this we deduce that,

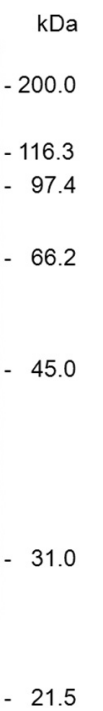

Fig. 2. SDS-PAGE (11\%) analysis of an avenin extract from A. sativa cultivar Gigant followed by PageBlue staining. The apparent weight on the gel is somewhat higher than the molecular weight of avenins of 'Gigant' (21-31 kDa) as predicted based on the sequences.

even if we not have cloned all members of the gene family from each accession, we did cover the diversity present in the gene family across the genus. The $\mathrm{N}$-terminal sequences exhibited a very high homology (S2), which is in accordance with the results presented by Pernollet et al. (1987). The length of the predicted proteins ranged from 187 to 270 AA. Differences in length were mainly due to presence of repetitive motifs within non-conserved regions (between positions 34-89 and 161-301 after the signal peptide). The predicted molecular weight of the avenins of 'Gigant' is 21$31 \mathrm{kDa}$, which is low in comparison to prolamins from wheat, rye and barley whose molecular weights range from 25 to $100 \mathrm{kDa}$ (Tatham et al., 2000).

\subsection{Presence of celiac disease epitopes in avenins}

To estimate the T-cell stimulatory capacity of oat avenins, all predicted avenin proteins were screened for the presence of known CD T cell epitopes [(Sollid et al., 2012) and variants thereof, as some substitutions may not abolish T cell activation (Mitea et al., 2010). Next, the potential protease resistance of the deduced peptides was

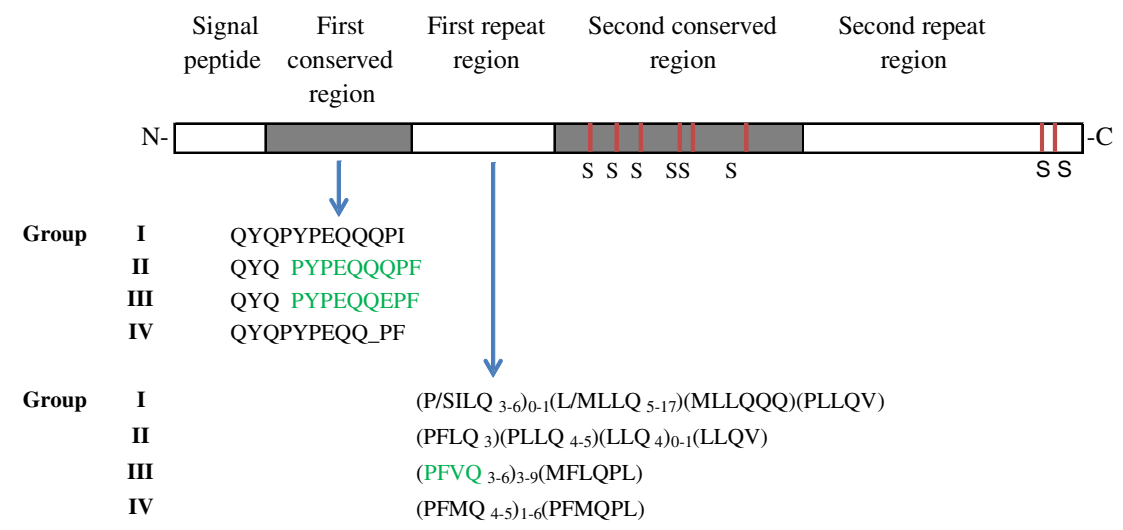

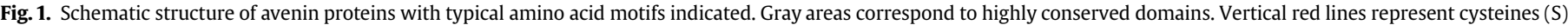

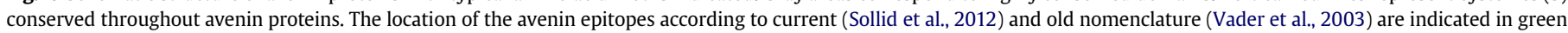
within the motifs. After Shewry et al. (1995). (For interpretation of the references to color in this figure legend, the reader is referred to the web version of this article.) 


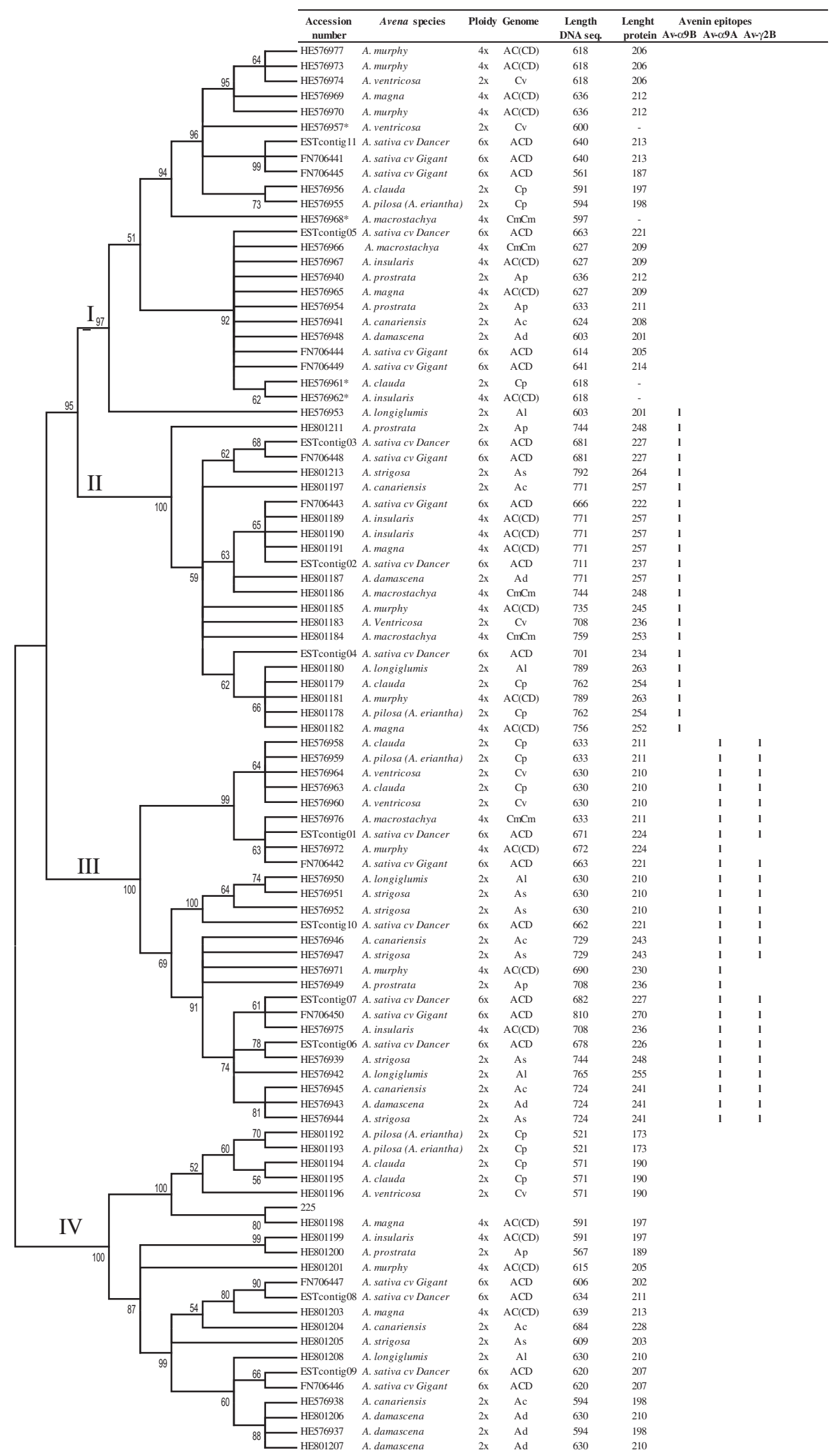

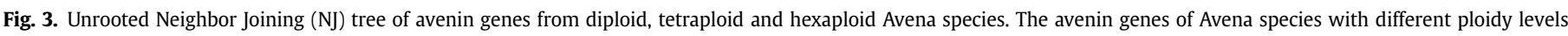

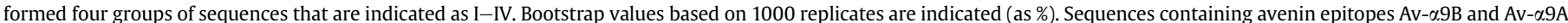

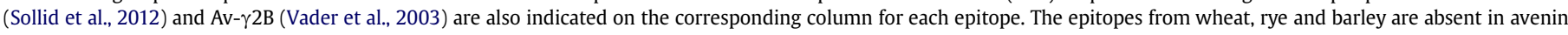
sequences of the species analyzed. 
Table 3

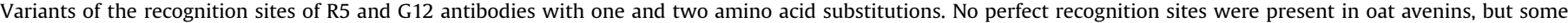
variants with one or two amino acid substitutions (in red and underlined) were found.

\begin{tabular}{|c|c|c|c|c|c|c|c|c|c|}
\hline \multirow{2}{*}{$\begin{array}{l}\text { Antibody } \\
\text { R5 }\end{array}$} & \multirow{2}{*}{$\begin{array}{l}\text { Reported antibody } \\
\text { recognition sites }\end{array}$} & \multicolumn{6}{|c|}{ Variant in oat avenins with one (R5) or two (G12) amino acid substitution } & \multirow{2}{*}{$\begin{array}{l}\text { \% sequences containing } \\
\text { the variant } \\
23.4\end{array}$} & \multirow{2}{*}{$\begin{array}{l}\text { Linked to } \\
\text { avenin epitopes } \\
++\end{array}$} \\
\hline & & Q & Q & $\mathrm{P}$ & $\mathrm{F}$ & $\underline{\mathrm{L}}$ & & & \\
\hline & & Q & Q & $\mathrm{P}$ & $\mathrm{F}$ & $\underline{\bar{V}}$ & & 27.6 & + \\
\hline & & $\mathrm{Q}$ & $\mathrm{Q}$ & $\mathrm{P}$ & $\mathrm{F}$ & $\underline{\bar{M}}$ & & 23.4 & - \\
\hline & QQPYP & $\underline{Y}$ & Q & $\mathrm{P}$ & $\mathrm{Y}$ & $\overline{\mathrm{P}}$ & & 100 & - \\
\hline \multirow[t]{6}{*}{ G12 } & QPQLPY & $\bar{Q}$ & $\mathrm{P}$ & Q & $\mathrm{L}$ & $\underline{Q}$ & $\underline{Q}$ & 73.4 & + \\
\hline & QPQQPY & Q & $\mathrm{P}$ & $\mathrm{Q}$ & Q & $\overrightarrow{\mathrm{Q}}$ & $\overrightarrow{\mathrm{A}}$ & 40.4 & + \\
\hline & & Q & $\underline{Q}$ & Q & Q & $\overline{\mathrm{P}}$ & $\underline{\bar{F}}$ & 48.9 & + \\
\hline & & $\mathrm{Q}$ & $\overrightarrow{\mathrm{P}}$ & $\mathrm{Q}$ & Q & $\underline{L}$ & $\overline{\mathrm{P}}$ & 14.9 & - \\
\hline & & $\mathrm{Q}$ & $P$ & $\mathrm{Q}$ & Q & $\overline{\mathrm{L}}$ & $\underline{\bar{S}}$ & 6.4 & - \\
\hline & QPQLPF & Q & $\mathrm{P}$ & Q & $\mathrm{L}$ & $\underline{\mathrm{Q}}$ & $\underline{\mathrm{L}}$ & 8.5 & + \\
\hline
\end{tabular}

analyzed. Finally, the occurrence of recognition sites for the R5 and the G12 antibodies was verified.

The avenin-specific T cell epitopes PYPEQQQPF (Av- $\alpha 9 \mathrm{~B})$ and PYPEQQEPF (Av- $\alpha 9 A)$ were present and occurred only once per protein. They were located in the first conserved region of avenin proteins: Av- $\alpha 9 \mathrm{~B}$ was present in all genes of group II, whereas Av$\alpha 9 A$ occurred in all genes of group III. The motif QQPFVQQQQPFVQQ which used to be considered as an epitope $(A v-\gamma 9 B)$ but according to the new nomenclature it does not fulfill all criteria (Sollid et al., 2012), was located immediately downstream of $A v-\alpha 9 A$ in the first repetitive region in most of the sequences of group III (Fig. 1, S2). Avenins of groups I and IV did not contain the canonical aveninspecific T cell epitopes but variants thereof: PYPEQQPFM in proteins of group IV, and PYPEQQQPI or PYPEQQQSI in proteins of group I. As a consequence, $A v-\alpha 9 B$ and $\bar{A} v-\alpha 9 A$ were found in avenins of the $A / D$ and the $C$ genomes, and in each of the 13 Avena species studied. Four of 10 avenin genes of hexaploid cultivar 'Gigant' contained at least one of the canonical avenin-specific T cell epitopes. In 'Dancer' 7 of 11 transcripts encoded one of these T cell epitopes ( 3 contained Av- $\alpha 9 \mathrm{~B}$ and 4 contained Av- $\alpha 9 \mathrm{~A})$.

None of the gluten $T$ cell epitopes from wheat, rye and barley were detected in avenins, but some variants with one, two and three amino acid substitutions were found (Table 2). The two variants with one amino acid substitution corresponded to the already described avenin $T$ cell epitopes. Interestingly, the variants with two and three substitutions were predicted to be proteolysed in the gastrointestinal tract when we performed the analysis using the known specificities of the three enzymes, trypsin, chymotrypsin, and pepsin. In this analysis also, the two described avenin epitopes did not completely resist proteolysis as the phenylalanine was removed, leaving QPYPEQQQP and QPYPEQQEP peptides. If pepsin is omitted from the analysis, some variants are predicted to survive digestion (Table 2).

We further screened our set of avenin proteins for the 5-mer and 6 -mer amino acid sequences that are recognized by the $\mathrm{R} 5$ antibody and the G12 antibody, respectively, which are used to detect gluten in an ELISA test. The R5 antibody recognizes QQPFP, LQPFP, LQPFP, QLPYP, and, to a lesser extent, QLPTF, QQSFP, QQTFP, PQPFP, QQPYP, and PQPFP (Valdes et al., 2003), with an overall recognition motif of $\mathrm{Q}(\mathrm{P})-\mathrm{Q}(\mathrm{P}, \mathrm{L})-\mathrm{Q}(\mathrm{L})-\mathrm{PF} / \mathrm{YP}$ (Osman et al., 2001). The G12 antibody recognizes the sequences QPQLPY, QPQQPY and QPQLPF (Moron et al., 2008). All those antibody recognition sequences were absent in avenin proteins. Variants of these recognition sites were present: with one amino acid difference for the R5 recognition site (Table 3), and with at least two amino acid differences for the G12 recognition site (Table 3 ). Two out of four R5-related variants and four out of six G12-related variants are present in sequences that also contain the avenin-specific epitopes, so it might be possible that they relate to the number of those epitopes but this relation should be proved. All those variants are predicted to be degraded by pepsin, trypsin and chymotrypsin.

\section{Discussion}

This work presents, for the first time, a thorough evaluation of the sequence diversity of avenin genes across the entire genus Avena (oat). We have studied the presence of celiac disease DQ2/8 T cell epitope sequences of wheat, barley and rye (according to current international agreement (Sollid et al., 2012)), the occurrence of the two avenin-specific CD epitopes (Arentz-Hansen et al., 2004), and the existence of recognition sequences of several $\mathrm{mAbs}$ that are applied in commercially available gluten detection kits. The results enable to discuss deeply the safety of oats for patients suffering from celiac disease and the limitations of in vitro immunogenicity data in heterologous plant material.

\subsection{Avenin gene number}

According to the estimations in oat made by Chesnut et al. (1989) based on Southern hybridization, and in line with large numbers of the homologous gliadin genes in wheat (van Herpen et al., 2006), at least 25 avenin genes (and pseudogenes) were expected to be present in oat. However, we detected only 10-11 avenin genes in the hexaploid cultivars 'Gigant' and 'Dancer'. It is possible that some cultivars contain loci with more genes through additional gene duplications. Alternatively, we may have underestimated the number of genes as we conservatively combined all sequences with $99 \%$ or higher similarity into one gene contig, thus possibly lumping highly similar genes. On the other hand, indirect evidence that the gene family is not very large comes from the fact that we did not find any pseudogenes in hexaploid $A$. sativa cultivars, and only very few in the sequences from other Avena species (overall 5 of 78 distinct avenin genes, or 6\%). Pseudogenes may be the hallmark of an expanded gene family of storage proteins (in wheat, $87 \%$ of the $\alpha$-gliadins were pseudogenes (van Herpen et al., 2006)). It is not likely that our primers systematically would have missed particular groups because EST sequences clustered in the same groups.

A low number of avenin genes compared to gluten genes in wheat is consistent with the difference in the prolamin fraction of the storage protein composition (10-15\% of the total seed protein content in oats, compared to about $80 \%$ in wheat (Tatham et al., 2000)). The low number of proteins is supported by the similar number of bands on an SDS-PAGE gel. van den Broeck et al. (2011) extracted avenins from a commercial oat flour and distinguished 12 protein bands (SDS-PAGE) and found that each band corresponded to a single avenin protein on a $2 \mathrm{D}$-gel. 


\subsection{Avenin gene family expansion}

A neighbor-joining analysis showed that the avenin gene sequences of the entire Avena genus representing the diploid, tetraploid and hexaploid species and genomes (A/D and C) (Loskutov, 2008) obtained in this paper, clustered in four groups (Fig. 3). The genes in the four groups differed from each other by sequence differences in the two conserved regions, and by differences in repeat motifs and the number of repeat units in the two repetitive regions (S2). The codon-based test for selection (Z-test) showed evidence for purifying selection for genes of each of the four groups. Each group consists of avenins from the $A$ and $C$ genomes of the diploid species, and of tetraploid and hexaploid Avena species. This indicates that the most recent common ancestor (MRCA) of the Avena genus most likely contained one or more representatives of each of the four avenin groups before the $\mathrm{A}$ and $\mathrm{C}$ genomes diverged. In the Groups III and IV, two genome-specific subgroups appear to exist: one subgroup with sequences from genome A and the other one with sequences from genome C. Repeat motifs within the first and the second repetitive regions of group IV contained methionine while the others did not. Chesnut et al. (1989) regarded this group as a separate protein subfamily. Absence of genomespecific subgroups in group II could be due to a lack of initial divergence (in agreement with the low diversity within this group) and/or incomplete lineage sorting. Presence of two A-genome subgroups in group III, each of them containing sequences of Avena strigosa and Avena longiglumis, may indicate a specific duplication of sequences of this group in the MRCA of at least some of the A genome diploid species. The allohexaploid species $A$. sativa contains avenins from each of the four groups and subgroups except the C-genomic subgroup of group IV, indicating that the allohexaploid has maintained all groups brought in by the three genomes.

\subsection{Phylogenetic origin}

There are some structural differences between avenins and other prolamins (especially those from wheat, barley and rye) regarding polymorphism, molecular weight and number and location of repetitive domains and cysteine residues (Shewry et al., 1995; Tatham et al., 2000). Alignment of the second conserved region of the avenins against EMBL/GenBank sequences (not shown) indicated that the highest degree of homology are gammatype S-rich prolamins, such as the gamma-secalins in barley and the gamma-hordeins in rye that all contain eight cysteine residues at similar positions. Similarly to secalins, none of the avenin sequences contained tryptophan. We confirmed the presence of aspartic acid in position 7 and its replacement by asparagine as shown by Pernollet et al. (1987), or, in some avenins, by tyrosine.

Thus, genus-wide cloning and sequencing of the avenins clearly showed the limited range of diversity of the avenin gene family. With this approach, for the first time, a complete picture of the avenins in oats has been obtained, as a basis to establish the safety of oat for $\mathrm{CD}$ patients.

\subsection{The safety of oats for people with celiac disease}

The safety and the diet-improving effect of oats for the majority of celiac patients is currently well-recognized (Pulido et al., 2009). It is fair to say that a large intervention study (although not intended as such) regarding the safety of oats is currently ongoing in the form of daily pragmatic practice of oat consumption in Scandinavia and The Netherlands, where Celiac patient societies stimulate oat-based food consumption from established glutenfree oat production chains, and where patients have a positive attitude on the gluten-free oat products. Seventy percent of $C D$ patients in Nordic countries and an increasing number of patients in The Netherlands eat oats regularly with full contentment (Salovaara et al., 2010). In addition, the advantages of oat consumption by diabetic individuals, as CD and diabetes regularly happen to coincide, are welcomed (personally communicated by the board of the Dutch Diabetic Society).

Toxicity problems of oat products, in general, are related to contamination with gluten, and, in some rare cases, to the presence of the two avenin-specific sequences harboring the epitopes Av$\alpha 9 \mathrm{~A}$ (PYPEQQEPF) and Av- $\alpha 9 \mathrm{~B}$ (PYPEQQQPF) that can induce an immune response in a few celiac patients (Arentz-Hansen et al., 2004; Lundin et al., 2003; Vader et al., 2003). Although the number of oat-sensitive patients appears to be very low, this aspect attained much attention and definitely caused reluctance in oat consumption by the celiac population. Peptides containing these two avenin epitopes turned out to be common in oat (Fig. 3).

\subsection{Antibody and $T$ cell tests}

Based on our extensive set of deduced avenin proteins we were, for the first time, able to determine that the 17 internationally accepted $C D$ epitopes from wheat, rye and barley that are recognized by CD4+ T cells (Sollid et al., 2012), as well as the p31-43 epitope that has been implicated in the innate immune response, are all absent in oat avenins. Variants of these epitopes do occur in oats, but they differ at two or three of the nine amino acid residues. None of them is predicted to survive digestion by pepsin, trypsin and chymotrypsin. Thus, they are unlikely to be clinically relevant. The two avenin-specific epitopes described by Arentz-Hanzen et al. (2004), to which few CD patients specifically react, were found in two of the four groups of avenins that occur in each of the genomes. Hence, these epitopes are probably present in all Avena species. Based on in silico proteolysis we predict that they also represent the most abundant protease-stable peptides. So, the question is what could cause the differential reaction of monoclonal antibodies and peripheral $\mathrm{T}$ cells in vitro to oat varieties. None of the recognition sites of the R5 and the G12 antibody tests are present in avenins. Only variant sequences with one (in the case of R5) or two (in the case of G12) amino acid residue difference were detected, some of which were linked to the avenin-specific epitopes (Table 3). Thus, the immunogenic responses that are described to oat extracts of some varieties (Comino et al., 2011; Mujico et al., 2011) are most likely the result of cross-reactivity with sequences present in avenins with one (R5) or two (G12) amino acid difference and this should be considered to be beyond the identified clinically toxic sequence profile (Sollid et al., 2012). Hence, the relation between the antibody signal and a $T$ cell response as established for gliadins in wheat and prolamins in rye and barley should not simply be extrapolated to oat.

\subsection{Limitations of test systems}

Thus, test systems that do not directly detect the intact epitopes are limited in their applicability, as the correlation between the antibody signal and the presence of intact epitopes as established for gliadins in wheat and prolamins in rye and barley, should not be extrapolated beyond these species (Sollid et al., 2012). This would appear obvious, but antibodies developed to detect gluten in wheat were used on the proven gluten-safe crops like the dicot Quinoa (Zevallos et al., 2012), which is not even a cereal. Without confirmation by other methods, such data are misleading to the overall patient population. Here, the scientific world should take its responsibility, and should be reluctant in sending out signals that might cause commotion among the patient society before relevance and extent of possible harm are reliably demonstrated. 


\section{Conclusion}

The genus-wide genomics analysis of the avenin gene family with regard to celiac disease $(C D)$ has shown that none of the internationally agreed epitopes from gluten of wheat, barley and rye are present in oat avenins. The presence of the two described avenin-epitopes was confirmed within a conserved avenin region in all Avena species examined, making it unlikely to find oat varieties that lack these sequences. Therefore, if responses of T cells of $\mathrm{CD}$ patients to oat extracts occur, they are most likely toward these two peptides. The monoclonal antibody signals (R5 and G12) are probably due to cross-reactive or promiscuous recognition of avenin peptides, and unless the relation with the two avenin-epitopes is proven, such signals should not be interpreted as differences in immunogenicity of oat varieties for $\mathrm{CD}$ patients.

\section{Acknowledgments}

This research was funded by the Celiac Disease Consortium, an Innovative Cluster approved by the Netherlands Genomics Initiative and partially funded by the Dutch Government (BSIK03009), by the Ministry of Economic Affairs ( KB05-001-019, KB05-003-032, KB15-001-007), and The Europees Fonds voor Regionale Ontwikkeling (EFRO), which is supported by the European Union and the province Gelderland

\section{Appendix A. Supplementary data}

Supplementary data related to this article can be found at http:// dx.doi.org/10.1016/j.jcs.2013.03.017.

\section{References}

Anderson, R.P., Degano, P., Godkin, A.J., Jewell, D.P., Hill, A.V.S., 2000. In vivo antigen challenge in celiac disease identifies a single transglutaminase-modified peptide as the dominant A-gliadin T-cell epitope. Nature Medicine 6, 337-342.

Andon, M., Anderson, J., 2008. The oatmeal-cholesterol connection: 10 years later. American Journal of Lifestyle Medicine 2, 51-57.

Arentz-Hansen, H., Fleckenstein, B., Molberg, O., Scott, H., Koning, F., Jung, G. Roepstorff, P., Lundin, K.E.A., Sollid, L.M., 2004. The molecular basis for oat intolerance in patients with Celiac disease. Plos Medicine 1, 84-92.

Chesnut, R.S., Shotwell, M.A., Boyer, S.K., Larkins, B.A., 1989. Analysis of avenin proteins and the expression of their messenger-RNAs in developing oat seeds. Plant Cell 1, 913-924.

Comino, I., Real, A., de Lorenzo, L., Cornell, H., López-Casado, M.Á., Barro, F., Lorite, P., Torres, M.I., Cebolla, Á., Sousa, C., 2011. Diversity in oat potential immunogenicity: basis for the selection of oat varieties with no toxicity in coeliac disease. Gut 60, 915-922.

Gelinas, P., McKinnon, C.M., Mena, M.C., Mendez, E., 2008. Gluten contamination of cereal foods in Canada. International Journal of Food Science and Technology 43, 1245-1252.

Janatuinen, E.K., Pikkarainen, P.H., Kemppainen, T.A., Kosma, V.M., Jarvinen, R.M.K., Uusitupa, M.I.J., Julkunen, R.J.K., 1995. A comparison of diets with and without oats in adults with celiac disease. New England Journal of Medicine 333, 10331037.

Koskinen, O., Villanen, M., Korponay-Szabo, I., Lindfors, K., Maki, M., Kaukinen, K., 2009. Oats do not induce systemic or mucosal autoantibody response in children with coeliac disease. Journal of Pediatric Gastroenterology and Nutrition $48,559-565$

Loskutov, I.G., 2008. On evolutionary pathways of Avena species. Genetic Resources and Crop Evolution 55, 211-220.

Lundin, K.E.A., Nilsen, E.M., Scott, H.G., Loberg, E.M., Gjoen, A., Bratlie, J., Skar, V., Mendez, E., Lovik, A., Kett, K., 2003. Oats induced villous atrophy in coeliac disease. Gut 52, 1649-1652.
Mitea, C., Salentijn, E.M.J., van Veelen, P., Goryunova, S.V., van der Meer, I.M., van den Broeck, H.C., Mujico, J.R., Montserrat, V., Gilissen, L.J.W.J., Drijfhout, J.W., Dekking, L., Koning, F., Smulders, M.J.M., 2010. A universal approach to eliminate antigenic properties of alpha-gliadin peptides in celiac disease. Plos One 5, e15637.

Moron, B., Cebolla, A., Manyani, H., Alvarez-Maqueda, M., Megias, M. Thomas, M.D.C., Lopez, M.C., Sousa, C., 2008. Sensitive detection of cereal fractions that are toxic to celiac disease patients by using monoclonal antibodies to a main immunogenic wheat peptide. American Journal of Clinical Nutrition 87, 405-414.

Mujico, J.R., Mitea, C., Gilissen, L.J.W.J., de Ru, A., van Veelen, P., Smulders, M.J.M., Koning, F., 2011. Natural variation in avenin epitopes among oat varieties: implications for Celiac disease. Journal of Cereal Science 54, 8-12.

Osman, A.A., Uhlig, H.H., Valdes, I., Amin, M., Mendez, E., Mothes, T., 2001. A monoclonal antibody that recognizes a potential toxic repetitive pentapeptide epitope in gliadins. European Journal of Gastroenterology \& Hepatology 13, 1189-1193.

Pernollet, J.-C., Huet, J.-C., Galle, A.-M., Sallantin, M., 1987. N-terminal sequences of oat avenins compared to other cereal prolamins. Biochimie 69, 683-689.

Pulido, O., Gillespie, Z., Zarkadas, M., Dubois, S., Vavasour, E., Rashid, M., Switzer, C., Godefroy, B.S., 2009. Introduction of oats in the diet of individuals with celiac disease: a systematic review. Advances in Food and Nutrition Research 57, 235-285.

Salentijn, E.M.J., Mitea, D.C., Goryunova, S.V., Van der Meer, I.M., Padioleau, I., Gillissen, L.J.W.J., Koning, F., Smulders, M.J.M., 2012. Celiac disease T cell epitopes from gamma-gliadins: immunoreactivity depends on the genome of origin, transcript frequency, and flanking protein variation. BMC Genomics 13, 277.

Salovaara, H.O., Kanerva, P., Loponen, J., Sontag-Strohm, T.S., 2010. Oats in glutenfree diet, considerations of a pragmatic policy. In: Second International Symposium on Gluten-free Cereal Products and Beverages. University of Helsinki, Tampere, Finland, pp. 193-194.

Shewry, P.R., Tatham, A.S., Barro, F., Barcelo, P., Lazzeri, P., 1995. Biotechnology of breadmaking: unraveling and manipulating the multi-protein gluten complex. Biotechnology 13, 1185-1190.

Silano, M., Di Benedetto, R., Maialetti, F., De Vincenzi, A., Calcaterra, R., Cornell, H.J., De Vincenzi, M., 2007. Avenins from different cultivars of oats elicit response by coeliac peripheral lymphocytes. Scandinavian Journal of Gastroenterology 42, 1302-1305.

Sollid, L.M., Qiao, S.W., Anderson, R.P., Gianfrani, C., Koning, F., 2012. Nomenclature and listing of celiac disease relevant gluten T-cell epitopes restricted by HLA-DQ molecules. Immunogenetics 64, 455-460.

Spaenij-Dekking, L., Kooy-Winkelaar, Y., Van Veelen, P., Drijfhout, J.W., Jonker, H., Van Soest, L., Smulders, M.J.M., Bosch, D., Gilissen, L., Koning, F., 2005. Natural variation in toxicity of wheat: potential for selection of nontoxic varieties for celiac disease patients. Gastroenterology 129, 797-806.

Tatham, A.S., Gilbert, S.M., Fido, R.J., Shewry, P.R., 2000. Extraction, separation and purification of wheat gluten proteins and related proteins of barley, rye and oats. Methods in Molecular Medicine 41, 55-73.

Thompson, T., 2003. Oats and the gluten-free diet. Journal of the American Dietetic Association 103, 376-379.

Tuire, I., Marja-leena, L., Teea, S., Katri, H., Jukka, P., Päivi, S., Heini, H., Markku, M., Pekka, C., Katri, K., 2012. Persistent duodenal intraepithelial lymphocytosis despite a long-term strict gluten-free diet in celiac disease. The American Journal of Gastroenterology 107, 1563-1569.

Vader, L.W., Stepniak, D.T., Bunnik, E.M., Kooy, Y.M.C., De Haan, W., Drijfhout, J.W., Van Veelen, P.A., Koning, F., 2003. Characterization of cereal toxicity for celiac disease patients based on protein homology in grains. Gastroenterology 125, 1105-1113.

Valdes, I., Garcia, E., Llorente, M., Mendez, E., 2003. Innovative approach to lowlevel gluten determination in foods using a novel sandwich enzyme-linked immunosorbent assay protocol. European Journal of Gastroenterology \& Hepatology 15, 465-474.

van den Broeck, H.C., Gilissen, L.J.W.J., Smulders, M.J.M., van der Meer, I.M., Hamer, R.J., 2011. Dough quality of bread wheat lacking alpha-gliadins with celiac disease epitopes and addition of celiac-safe avenins to improve dough quality. Journal of Cereal Science 53, 206-216.

van Herpen, T., Goryunova, S.V., van der Schoot, J., Mitreva, M., Salentijn, E., Vorst, O, Schenk, M.F, van Veelen, P.A, Koning, F, van Soest, LJ.M., Vosman, B. Bosch, D., Hamer, R.J., Gilissen, L.J.W.J., Smulders, M.J.M., 2006. Alpha-gliadin genes from the A, B, and D genomes of wheat contain different sets of celiac disease epitopes. BMC Genomics 7, 1.

Zevallos, V.F., Ellis, H.J., Šuligoj, T., Herencia, L.I., Ciclitira, P.J., 2012. Variable activation of immune response by quinoa (Chenopodium quinoa Willd.) prolamins in celiac disease. The American Journal of Clinical Nutrition 96, 337-344. 